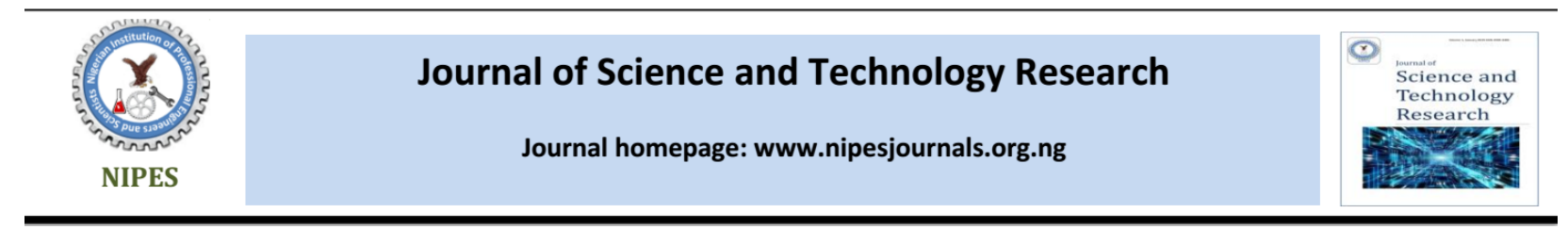

\title{
Analysis of Frequent Power Cut on Ugbowo 2x15MVA, 33/11kV Electric Power Distribution Network Feeders
}

\author{
${ }^{1}$ France O. Akpojedje and ${ }^{2}$ Emmanuel A. Ogujor \\ ${ }^{1}$ Department of Electrical/Electronic Engineering Technology, National Institute of Construction Technology and Management \\ (NICTM), Uromi, Nigeria. \\ ${ }^{2}$ Department of Electrical/Electronic Engineering, University of Benin, Benin City, Nigeria. \\ Corresponding Author: francetech007@yahoo.com, oguemma@yahoo.com
}

\begin{tabular}{l} 
Article Info \\
\hline Received 15 August 2020 \\
Revised 19 August 2020 \\
Accepted 20 August 2020 \\
Available online 31 August 2020 \\
\hline
\end{tabular}

Keywords:

Failure rate, Feeder, Frequent outage, Mean time to failure, Mean time to repair, Unavailability

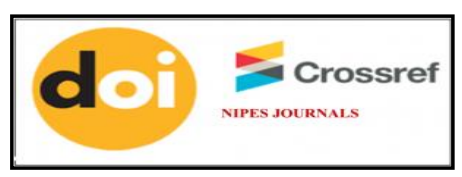

https://doi.org/10.37933/nipes/2.3.2020.30

https://nipesjournals.org.ng (c) 2020 NIPES Pub. All rights reserved

\begin{abstract}
This paper investigates the frequent power cut on the $11 \mathrm{kV}$ feeders of Ugbowo 2x15MVA, 33/11kV electric power distribution network. Annual data of daily power outages from August 2019 to July 2020 of the $11 \mathrm{kV}$ feeders were collated and collected from the Ugbowo distribution network. The daily outages of the $11 \mathrm{kV}$ feeders were used to compute the monthly and the yearly reliability indices of the feeders of the Ugbowo distribution network. Both the monthly and annual failure rates, MTTR, MTTF, MTBF, availability and unavailability were computed and analyzed using the Load Point Indices (LPI) and the Microsoft Excel was used for graphical interpretation in order to estimate the reliability indices and to determine the frequency of power outages of the network. Also, the Performance Indices (PI) of the system were evaluated for an in-depth assessment. The annual and monthly failure rates, mean time to repair, mean time to failure, mean time between failure, system average interruption frequency indices (SAIFI), system average interruption duration indices (SAIDI), average service availability index (ASAI), etc for a period of twelve (12) months were analyzed. The computed results obtained from the analyses of the $11 \mathrm{kV}$ feeders of the distribution network showed that the power unavailability is very high for the period under study with Ugbowo $11 \mathrm{kV}$ feeder having the highest power unavailability of $76.52 \%$, Eguaedaiken $11 \mathrm{kV}$ feeder $73.42 \%$, FGGC $11 \mathrm{kV}$ feeder $69.50 \%$ and Uselu $11 \mathrm{kV}$ feeder $66.96 \%$ in the network. The annual failure rate results revealed that Ugbowo $11 \mathrm{kV}$ feeder has the highest failure rate of $46.52 \%$, followed by Eguaedaiken feeder $44.83 \%$, FGGC feeder $44.27 \%$ and Uselu feeder $41.60 \%$. This is due to frequent power outages resulting from regimented load shedding (scheduled outages) being practice in the network as way to manage equipment limitations, poor energy management system, etc. and unscheduled (forced) outages due to faults in the network. Furthermore, the PI of the system revealed that the annual total outage duration (SAIDI), outage frequency (SAIFI) and percentage availability (ASAI) were 175.7504 hours, 3.3780f/cu.yr and $97.99 \%$ which is a far cry from the international acceptable standard value (IASV) of 2.5 hours, 0.01 and $99.99 \%$ respectively which showed that the power supply services in the network is unreliable.
\end{abstract}

\section{Introduction}

A reliable and continuous electricity supply is a hallmark of economy growth and socioeconomic development. In other words, electricity consumers' satisfaction and the availability of electricity 
supply is of importance priority to utility companies. But for the past decades and even currently, the frequent blackout experienced by the Nigerian electricity consumers have become worrisome to every stakeholder, especially the electrical engineers. The incessant and frequent power outage (cut) in the Nigerian electric power distribution system is a recurrent decimal and this is tag as one of the biggest obstacles to be tackled in the distribution section of the Nigeria electric power systems [1]. The need to assess the tripping profile of the $11 \mathrm{kV}$ feeders in the Ugbowo $2 \times 15 \mathrm{MVA}, 33 / 11 \mathrm{kV}$ distribution network has become crucial owing to the fact that consumers complains arising from the frequent outages have become alarming and the reasons for the frequent power outages in the network $11 \mathrm{kV}$ feeders is not far fetch. Power outage (cut or failure or blackout) is defined as a short or long term loss of electric power supply to consumers for a period of time [2]. Power outages affect the availability and reliability of electricity supply to customers and also, its quality. According to [3], the rate of reliable electricity produced, distributed and utilized by any nation is positively correlated to its overall Gross Domestic Product (GDP). In other words, frequent power cut has negative effect on economy growth and social development of the country. The reasons for the frequent power cut experienced in the network are not far fetch from unscheduled (forced) and scheduled (load shedding) outages [4]. The forced (unscheduled) outages occur as a result of faults which is predominant in conventional distribution system. According to [4], unscheduled interruptions (outages) are commonly predominant with conventional (traditional) electric power distribution network today. The unprecedented rise in the tripping profile of the $11 \mathrm{kV}$ feeders in the Ugbowo distribution network is due to load shedding (scheduled outages) currently practice by the Distribution System Operators (DSOs) to manage the equipment limitation in the network and also, manage the available electricity supply with the ever-growing energy demand by consumers in the network. So, the frequent blackout occurring in the network has resulted to poor availability and reliability in the system. According to [5], the poor reliability of electricity supply in Nigeria power systems has made it one of the markets for generators dealers across the world and the overall effect of this anomaly is an increase in pollution, increase in noise level etc. Frequent power cut is one of the major causes for poor performance of the distribution network, then its frequent power outages and reliability assessment cannot be overemphasized [6]. Since distribution network outages have localized effect compared to generating stations and transmission network which are system wide; less attention has been given to the distribution network availability and reliability modeling/estimation. According to [7], it has been observed that the analysis of customer failure statistics of most utilities showed that the distribution system makes the greatest individual contributions to the unavailability of electricity supply to consumers. Hence, this paper presents an appraisal of the network availability vis-à-vis the analysis of frequent outages of the $11 \mathrm{kV}$ feeders of the Ugbowo 2x15MVA, 33/11kV electric power distribution network.

\section{Methodology}

The research analysis carried out involves personal consultation and interview of energy consumers of the network and the staff of Benin Electricity Distribution Company (BEDC) domicile in the Ugbowo $2 \times 15 \mathrm{MVA}, 33 / 11 \mathrm{kV}$ injection substation. The data was collected for the period of twelve (12) months (August 2019 to July 2020) from the following materials of the injection substation:

i. Daily hourly load scheduled logbook kept in the Ugbowo $2 \times 15 \mathrm{MVA}, 33 / 11 \mathrm{kV}$ injection substation, Ugbowo, Benin City.

ii. Daily shift report logbook kept in the Ugbowo 2x15MVA, 33/11kV injection substation

iii. Daily report logbook of faults recorded in the distribution network.

iv. Personal interaction with the competent distribution system operators (DSOs) for technical guidance and information.

v. Physical inspection of the recording meters of the panels of the Ugbowo $2 \times 15 \mathrm{MVA}$, $33 / 11 \mathrm{kV}$ injection substation. 
The daily power failure data of the unscheduled and scheduled outages of the Ugbowo 2x15MVA, $33 / 11 \mathrm{kV}$ injection substation were obtained from the substation logbooks for the period under study, for the $11 \mathrm{kV}$ feeders connected to $2 \times 15 \mathrm{MVA}, 33 / 11 \mathrm{kV}$ power transformers of the substation. The data collected from the injection substation logbooks were analyzed using Load Point Indices (LPI) to calculate the failure rate, mean time to repair, mean time to failure, mean time between failure, availability, unavailability, while the Performance Indices (PI) of the system was used to determine SAIFI, SAIDI, ASAI, etc and the results obtained were interpreted graphically using Microsoft Excel.

\subsection{Reliability Indices}

Reliability indices (RI) are essential metrics for evaluating the distribution network performance. The reliability metrics are statistical tool used to analyze data of a well-designed set of loads, component or customers' satisfaction. Most reliability characteristic of component, feeder or entire system are determined by their functionality using historical data. Power companies commonly use two reliability indices which are frequency and duration to assess the performance of their systems or component. The following briefly describe the reliability and customer orientated indices:

2.1.1 Failure Rate $(\lambda)$ : is defined as the basic index of reliability which measure the frequency at which fault occurs in the system.

Failure Rate $(\lambda)=\frac{\text { Frequency of Outage } / \text { year or month }}{\text { Total Hours of Available } / \text { year or month }}$

2.1.2 Mean Time to Failure (MTTF): is a reliability metrics that defined the function of nonrepairable equipment in a given system.

Mean Time to Failure $(M T T F)=\frac{1}{\lambda}$

2.1.3 Mean Time to Repair or Recovery $(M T T R)$ : it is the average time needed to repair a faulty system or component and bring it back to its full operating state.

MTTR $=\frac{\text { Total System Downtime }}{\text { Number of Outage }}=\frac{1}{\mu}$

2.1.4 Mean Time between Failure (MTBF): it is the average time interval between consecutive failures of a repairable system or component.

$M T B F=\frac{\text { Total System } \text { Operating Hours }}{\text { Number of Outage }}=$ MTTF + MTTR

2.1.5 Availability $(A)$ : is the probability that an equipment or system will be available to perform the desired function when needed.

Availability $(A)=\frac{\text { Uptime }}{\text { Expected Uptime }}=\frac{\mu}{\lambda+\mu}=\frac{M T B F-M T T R}{M T B F}=\frac{M T T F}{M T T F+M T T R}$

2.1.6 Unavailability $(U)$ : it is the average time interval in which a system or component is not available to perform the required function. 
F. O. Akpojedje and E.A. Ogujor / NIPES Journal of Science and Technology Research 2(3) 2020 pp. 314-327

Unavailability $(U)=\frac{M T T R}{M T T F+M T T R}=1-\frac{M T T F}{M T T F+M T T R}=1-A$

2.1.7 Reliability $(R)$ : it is the probability that a system or device perform a function correctly when needed to do so.

$R=e^{-\lambda t}$

Where $\lambda=$ failure rate, $t=$ time of outage

2.1.8 System Average Interruption Frequency Index (SAIFI): it is the measure of how many sustained interruptions for an average consumer will experience during the period of a year.

SAIFI $=\frac{\text { Frequency of Outage }}{\text { Number of Customer Served }}=\frac{\sum \lambda i N i}{I N i}$

2.1.9 System Average Interruption Duration Index (SAIDI): it defines the measure of how many interruption hours an average customer will experience during the period of a year.

SAIDI $=\frac{\text { Total Outage Duration in Hours }}{\text { Number of Customer Served }}=\frac{\sum \text { UiNi }}{\varepsilon N i}$

2.1.10 Customer Average Interruption Duration Index (CAIDI): it defines the average length of an interruption as regard the number of customers affected for a specific period of time. It is also the average time needed to restore supply to the average customer per sustained interruption.

CAIDI $=\frac{\text { Sum of Customer Interruption Duration }}{\text { Total Number of Customer Interruption }}=\frac{\text { SAIDI }}{\text { SAIFI }}=\frac{\sum U i N i}{\epsilon \lambda i N i}$

2.1.11 Average Service Availability Index ( $A S A I)$ : it defines the measure of the average availability of the distribution network services to customers.

$A S A I=\frac{\text { Customer Hours of Available Service }}{\text { Customer Hours Demanded }}=\frac{\text { INix8760- }- \text { UiNi }}{\text { INix8760 }}$

2.1.12 Average Service Unavailability Index (ASUI): it defines the measure of the average unavailability of the distribution system services to customers.

$A S U I=\frac{\text { Customer Hours of Unavailable Service }}{\text { Customer Hours Demanded }}=1-A S A I=\frac{\sum \text { UiNi }}{\text { INix8760 }}$

\section{Results and Discussion}

The following section presents the results and discussion of the research work.

\subsection{Results}

This subsection presents the results obtained from the Ugbowo $2 x 15 \mathrm{MVA}, 33 / 11 \mathrm{kV}$ injection substation frequent power cut assessment of the $11 \mathrm{kV}$ feeders of the network. The results involve load point indices, system performance indices and the discussion are carried out in the subsequent subsection of this paper. 
F. O. Akpojedje and E.A. Ogujor / NIPES Journal of Science and Technology Research 2(3) 2020 pp. 314-327

Table 1: Monthly Computed Failure Rate of each Feeders of Ugbowo 2x15MVA, 33/11kV Injection Substation

\begin{tabular}{|l|l|l|l|l|l|l|l|l|l|l|l|l|}
\hline Months & JAN & FEB & MARCH & APRIL & MAY & JUNE & JULY & AUG & SEPT & OCT & NOV & DEC \\
\hline FGeder & & & & & & & & & & & & \\
\hline Uselu & 0.575 & 0.554 & 0.400 & 0.407 & 0.480 & 0.503 & 0.404 & 0.374 & 0.430 & 0.385 & 0.414 & 0.519 \\
\hline Eguaed & 0.362 & 0.686 & 0.450 & 0.472 & 0.328 & 0.350 & 0.404 & 0.342 & 0.537 & 0.368 & 0.391 & 0.544 \\
\hline Ugbowo & 0.343 & 0.569 & 0.479 & 0.472 & 0.522 & 0.438 & 0.515 & 0.527 & 0.316 & 0.455 & 0.517 & 0.398 \\
\hline
\end{tabular}

Table 2: Monthly Computed Mean Time to Failure of each Feeders of Ugbowo 2x15MVA, 33/11kV Injection Substation

\begin{tabular}{|l|l|l|l|l|l|l|l|l|l|l|l|l|}
\hline $\begin{array}{l}\text { Months } \\
\text { Feeder }\end{array}$ & JAN & FEB & MARCH & APRIL & MAY & JUNE & JULY & AUG & SEPT & OCT & NOV & DEC \\
\hline FGGC & 1.739 & 1.805 & 2.500 & 2.457 & 2.083 & 1.988 & 2.475 & 2.674 & 2.326 & 2.597 & 2.415 & 1.926 \\
\hline Uselu & 2.762 & 1.458 & 2.222 & 2.119 & 3.049 & 2.857 & 2.475 & 2.924 & 1.862 & 2.717 & 2.558 & 1.838 \\
\hline Eguaed. & 3.040 & 1.757 & 2.088 & 2.119 & 1.916 & 2.283 & 1.942 & 1.898 & 3.165 & 2.198 & 1.751 & 2.513 \\
\hline Ugbowo & 2.915 & 1.227 & 2.262 & 2.232 & 1.761 & 2.488 & 2.331 & 2.558 & 2.188 & 2.070 & 1.692 & 2.083 \\
\hline
\end{tabular}

Table 3: Monthly Computed Mean Time to Repair of each Feeders of Ugbowo 2x15MVA, 33/11kV Injection Substation

\begin{tabular}{|l|l|l|l|l|l|l|l|l|l|l|l|l|}
\hline \multicolumn{1}{|l|}{ Months } & JAN & FEB & MARCH & APRIL & MAY & JUNE & JULY & AUG & SEPT & OCT & NOV & DEC \\
\hline FGGC & 6.716 & 5.296 & 5.955 & 4.673 & 4.017 & 5.210 & 5.609 & 3.741 & 3.879 & 5.072 & 5.674 & 7.375 \\
\hline Uselu & 5.693 & 5.171 & 5.293 & 4.034 & 3.051 & 4.340 & 5.609 & 4.094 & 4.345 & 4.878 & 6.012 & 7.345 \\
\hline Eguaed & 6.623 & 7.649 & 9.015 & 6.452 & 5.663 & 5.626 & 6.609 & 5.694 & 3.561 & 5.552 & 6.076 & 7.276 \\
\hline Ugbowo & 9.279 & 9.318 & 7.526 & 7.500 & 6.065 & 6.513 & 8.776 & 5.274 & 5.010 & 6.483 & 7.907 & 6.774 \\
\hline
\end{tabular}

Table 4: Monthly Computed Mean Time between Failure of each Feeders of Ugbowo 2x15MVA, 33/11kV Injection Substation

\begin{tabular}{|l|l|l|l|l|l|l|l|l|l|l|l|l|}
\hline $\begin{array}{l}\text { Months } \\
\text { Feeder }\end{array}$ & JAN & FEB & MARCH & APRIL & MAY & JUNE & JULY & AUG & SEPT & OCT & NOV & DEC \\
\hline FGGC & 8.455 & 7.101 & 8.455 & 7.130 & 6.100 & 7.198 & 8.084 & 6.415 & 6.205 & 7.669 & 8.089 & 9.301 \\
\hline Uselu & 8.455 & 6.629 & 7.515 & 6.153 & 6.100 & 7.197 & 8.084 & 7.018 & 6.207 & 7.595 & 8.570 & 9.183 \\
\hline Eguaed. & 9.663 & 9.406 & 11.103 & 8.571 & 7.579 & 7.909 & 8.551 & 7.592 & 6.726 & 7.750 & 7.827 & 9.789 \\
\hline Ugbowo & 12.194 & 10.545 & 9.788 & 9.732 & 7.826 & 9.001 & 11.107 & 7.832 & 7.198 & 8.553 & 5.599 & 8.857 \\
\hline
\end{tabular}

Table 5: Monthly Computed Availability of each Feeders of Ugbowo 2x15MVA, 33/11kV Injection Substation

\begin{tabular}{|l|l|l|l|l|l|l|l|l|l|l|l|l|}
\hline \multicolumn{1}{|l|}{ Months } & JAN & FEB & MARCH & APRIL & MAY & JUNE & JULY & AUG & SEPT & OCT & NOV & DEC \\
\hline FGGC & 0.206 & 0.254 & 0.296 & 0.345 & 0.341 & 0.276 & 0.306 & 0.417 & 0.375 & 0.339 & 0.299 & 0.207 \\
\hline Uselu & 0.327 & 0.220 & 0.296 & 0.344 & 0.500 & 0.397 & 0.306 & 0.417 & 0.300 & 0.358 & 0.298 & 0.200 \\
\hline Eguaed. & 0.315 & 0.187 & 0.188 & 0.247 & 0.253 & 0.289 & 0.227 & 0.250 & 0.471 & 0.284 & 0.224 & 0.257 \\
\hline Ugbowo & 0.239 & 0.116 & 0.231 & 0.229 & 0.225 & 0.276 & 0.210 & 0.355 & 0.304 & 0.242 & 0.302 & 0.235 \\
\hline
\end{tabular}


F. O. Akpojedje and E.A. Ogujor / NIPES Journal of Science and Technology Research 2(3) 2020 pp. 314-327

Table 6: Monthly Computed Unavailability of each Feeders of Ugbowo 2x15MVA, 33/11kV Injection Substation

\begin{tabular}{|l|l|l|l|l|l|l|l|l|l|l|l|l|}
\hline Meeder & JAN & FEB & MARCH & APRIL & MAY & JUNE & JULY & AUG & SEPT & OCT & NOV & DEC \\
\hline FGGC & 0.794 & 0.746 & 0.704 & 0.655 & 0.659 & 0.724 & 0.694 & 0.583 & 0.625 & 0.661 & 0.701 & 0.793 \\
\hline Uselu & 0.673 & 0.780 & 0.704 & 0.656 & 0.500 & 0.603 & 0.694 & 0.583 & 0.700 & 0.642 & 0.702 & 0.800 \\
\hline Eguaed. & 0.685 & 0.813 & 0.812 & 0.753 & 0.747 & 0.711 & 0.773 & 0.750 & 0.529 & 0.716 & 0.776 & 0.743 \\
\hline Ugbowo & 0.761 & 0.884 & 0.769 & 0.771 & 0.775 & 0.724 & 0.790 & 0.645 & 0.696 & 0.758 & 0.698 & 0.765 \\
\hline
\end{tabular}

Table 7: Annual Computed Reliability Indices

\begin{tabular}{|l|l|l|l|l|l|l|l|l|}
\hline AUGUST 2019 TO JULY 2020 & $\begin{array}{l}\text { MTRF } \\
\text { Outages }\end{array}$ & $\begin{array}{l}\text { Duration of } \\
\text { Outages }\end{array}$ & $\begin{array}{l}\text { Failure } \\
\text { Rate } \\
(\boldsymbol{\lambda})\end{array}$ & MTBF & MTTF & MTTR & $\begin{array}{l}\text { Availability } \\
(\boldsymbol{A})\end{array}$ & $\begin{array}{l}\text { Unavailability } \\
(\boldsymbol{U})\end{array}$ \\
\hline FGGC & 1183 & 6088 & 0.4427 & 7.4051 & 2.2589 & 5.1462 & 0.3050 & 0.6950 \\
\hline Uselu & 1204 & 5866 & 0.4160 & 7.2759 & 2.4038 & 4.8721 & 0.3304 & 0.6696 \\
\hline Eguaed. & 1044 & 6431 & 0.4483 & 8.3906 & 2.2306 & 6.1600 & 0.2658 & 0.7342 \\
\hline Ugbowo & 957 & 6703 & 0.4652 & 9.1538 & 2.1496 & 7.0042 & 0.2348 & 0.7652 \\
\hline
\end{tabular}

Table 8: System Performance Indices

\begin{tabular}{|l|l|}
\hline Index & Value \\
\hline SAIFI & $3.3780 \mathrm{f} /$ customer.yr \\
\hline SAIDI & $175.7564 \mathrm{hr} /$ customer.yr \\
\hline CAIDI & $62.184 \mathrm{hr} /$ customer interruption \\
\hline ASAI & $0.9799 \mathrm{pu}$ \\
\hline ASUI & $0.02006 \mathrm{pu}$ \\
\hline EENS & $3178.680 \mathrm{MW} \mathrm{hr} / \mathrm{yr}$ \\
\hline ECOST & $7,716,760.00 \$ / \mathrm{yr}$ \\
\hline AENS & $22.3851 \mathrm{MW} \mathrm{hr} /$ customer.yr \\
\hline IEAR & $8.0203 \$ \mathrm{~kW} \mathrm{hr}$ \\
\hline
\end{tabular}

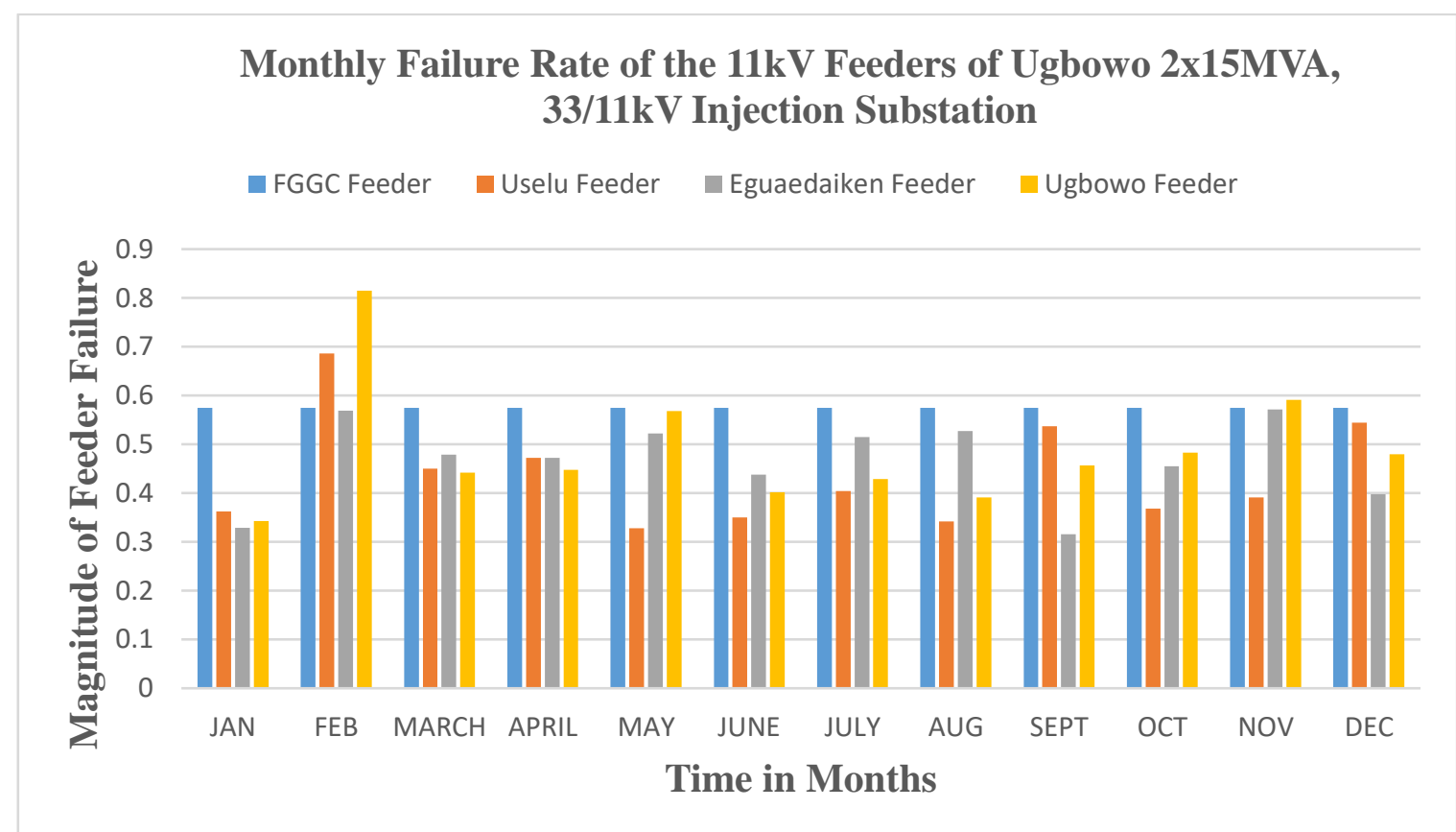

Figure 1: Monthly Failure Rate of each Feeder of Ugbowo 2x15MVA, 33/11kV Injection Substation 
F. O. Akpojedje and E.A. Ogujor / NIPES Journal of Science and Technology Research 2(3) 2020 pp. 314-327

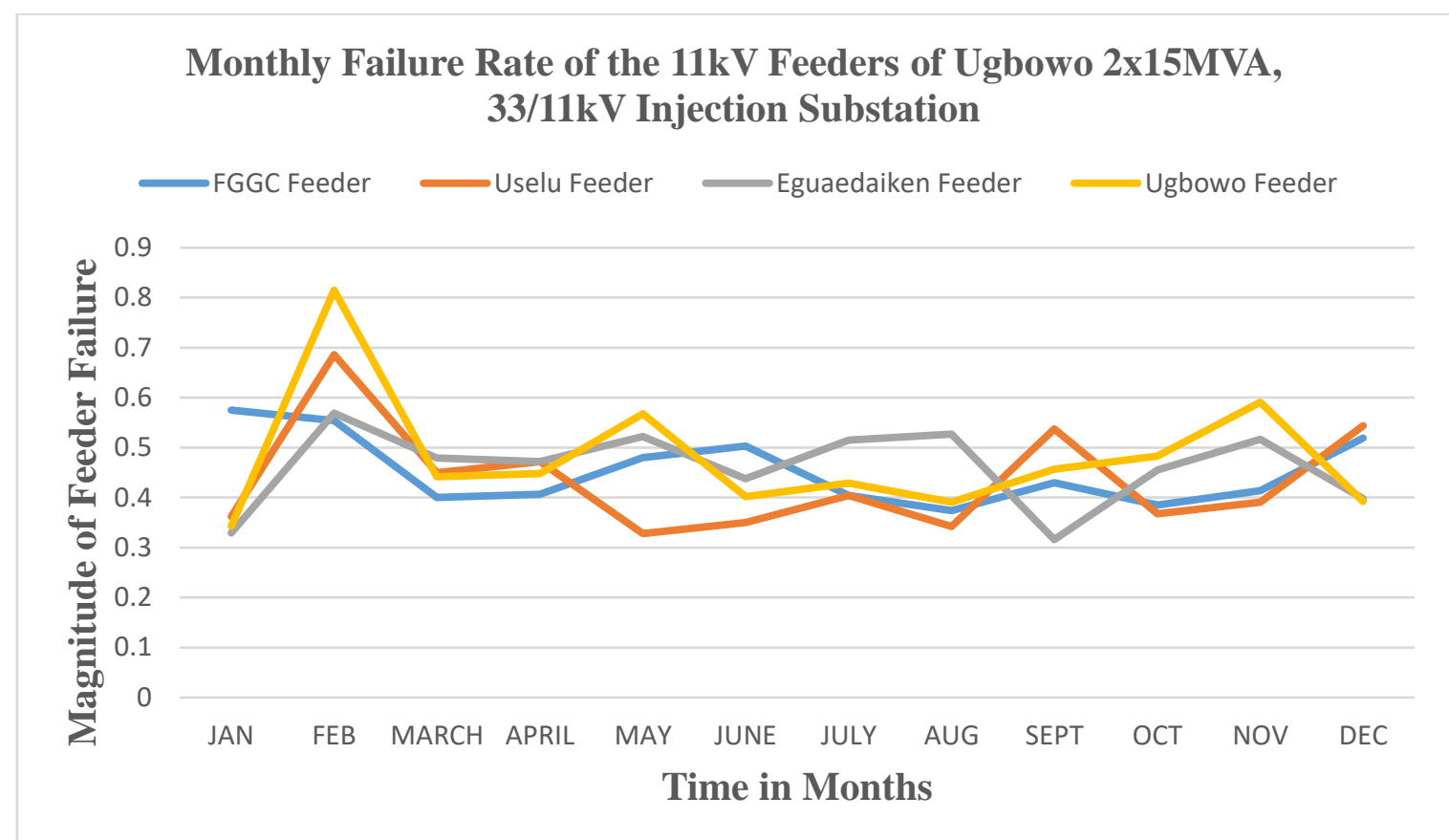

Figure 2: Monthly Failure Rate of the Four Feeders of Ugbowo 2x15MVA, 33/11kV Injection Substation

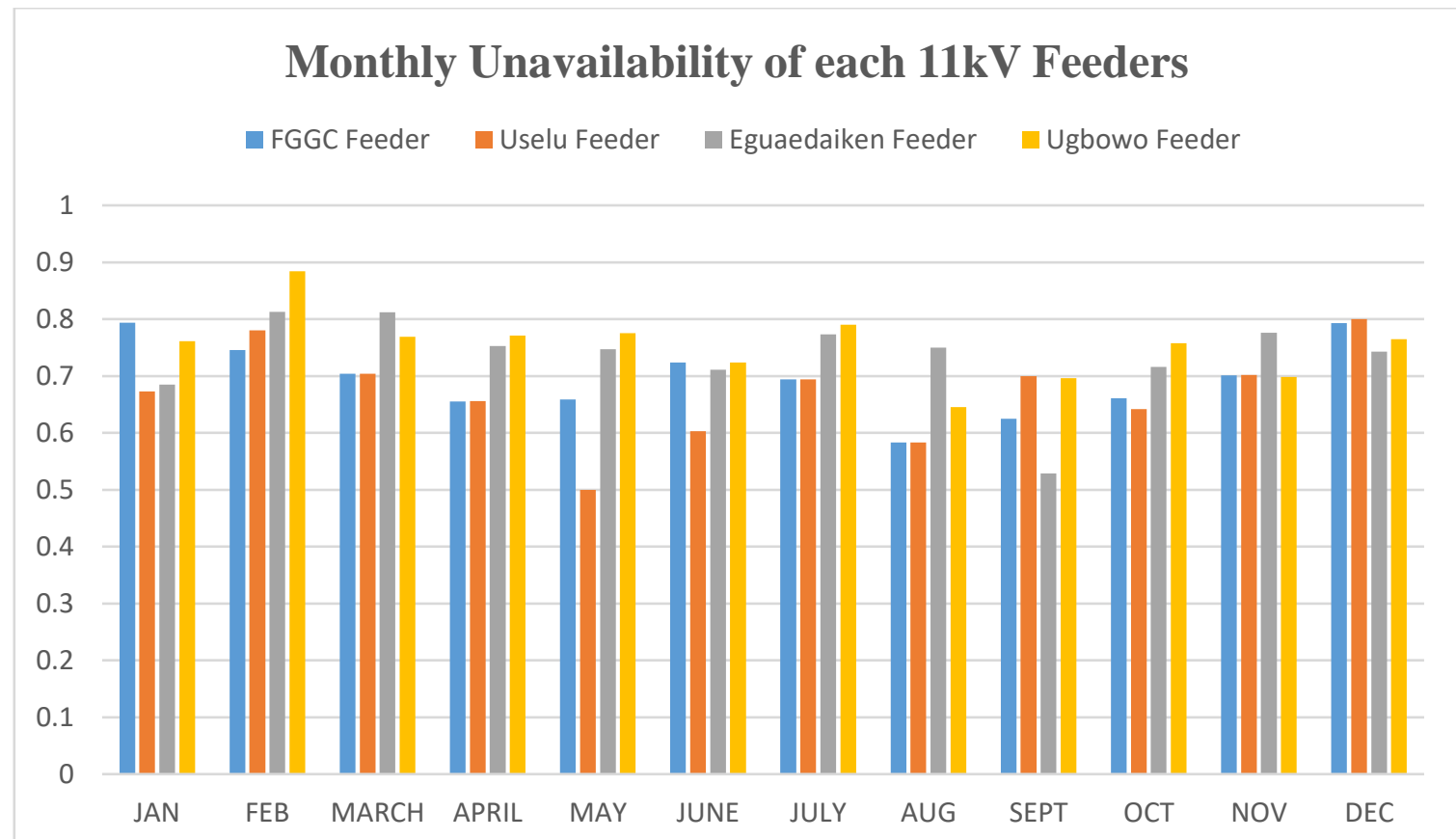

Figure 3: Monthly Unavailability of each $11 \mathrm{kV}$ Feeder of the Ugbowo 2x15MVA, 33/11kV Injection Substation 
F. O. Akpojedje and E.A. Ogujor / NIPES Journal of Science and Technology Research 2(3) 2020 pp. 314-327

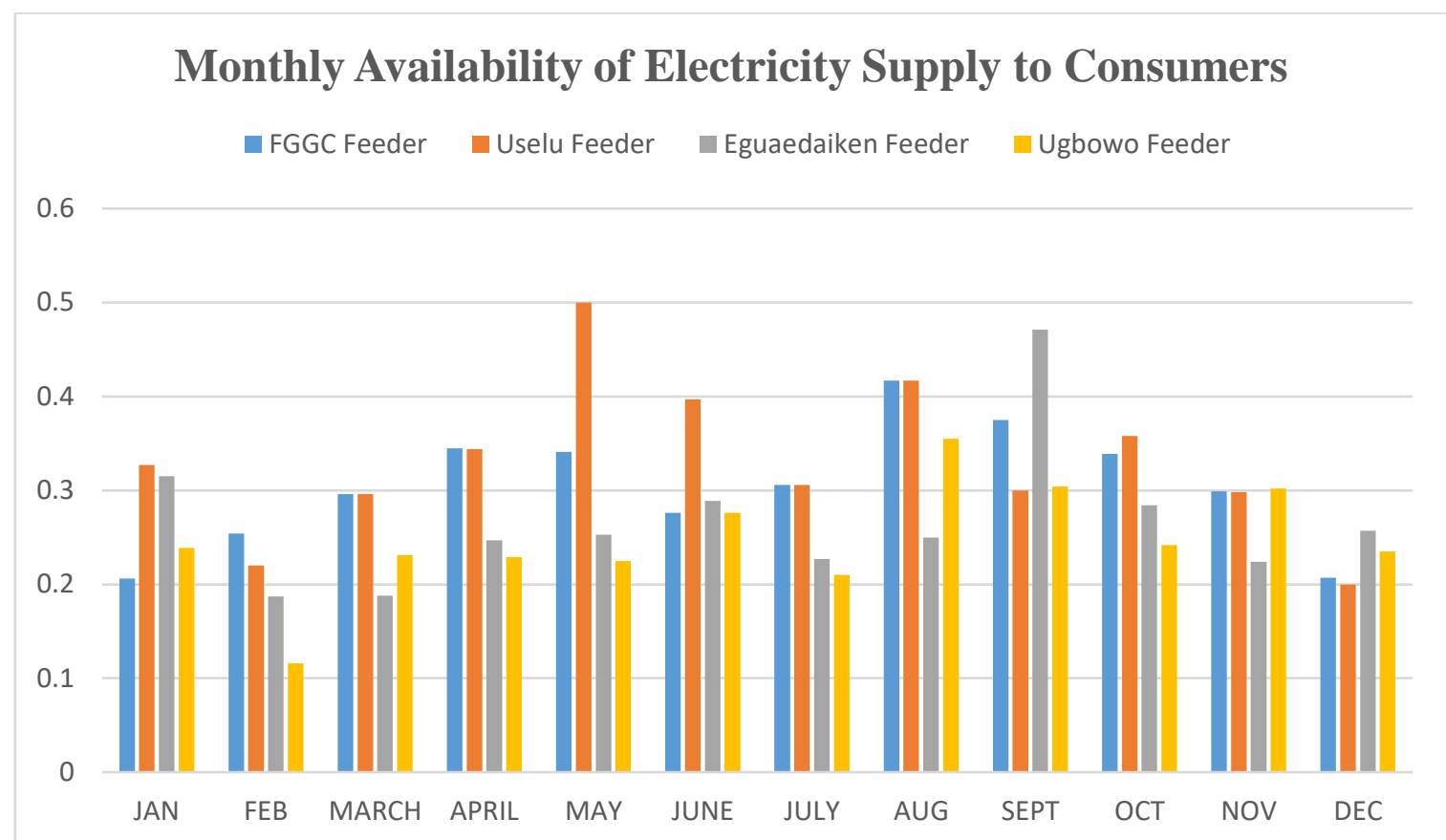

Figure 4: Monthly Availability of each $11 \mathrm{kV}$ Feeder of the Ugbowo 2x15MVA, 33/11kV Injection Substation

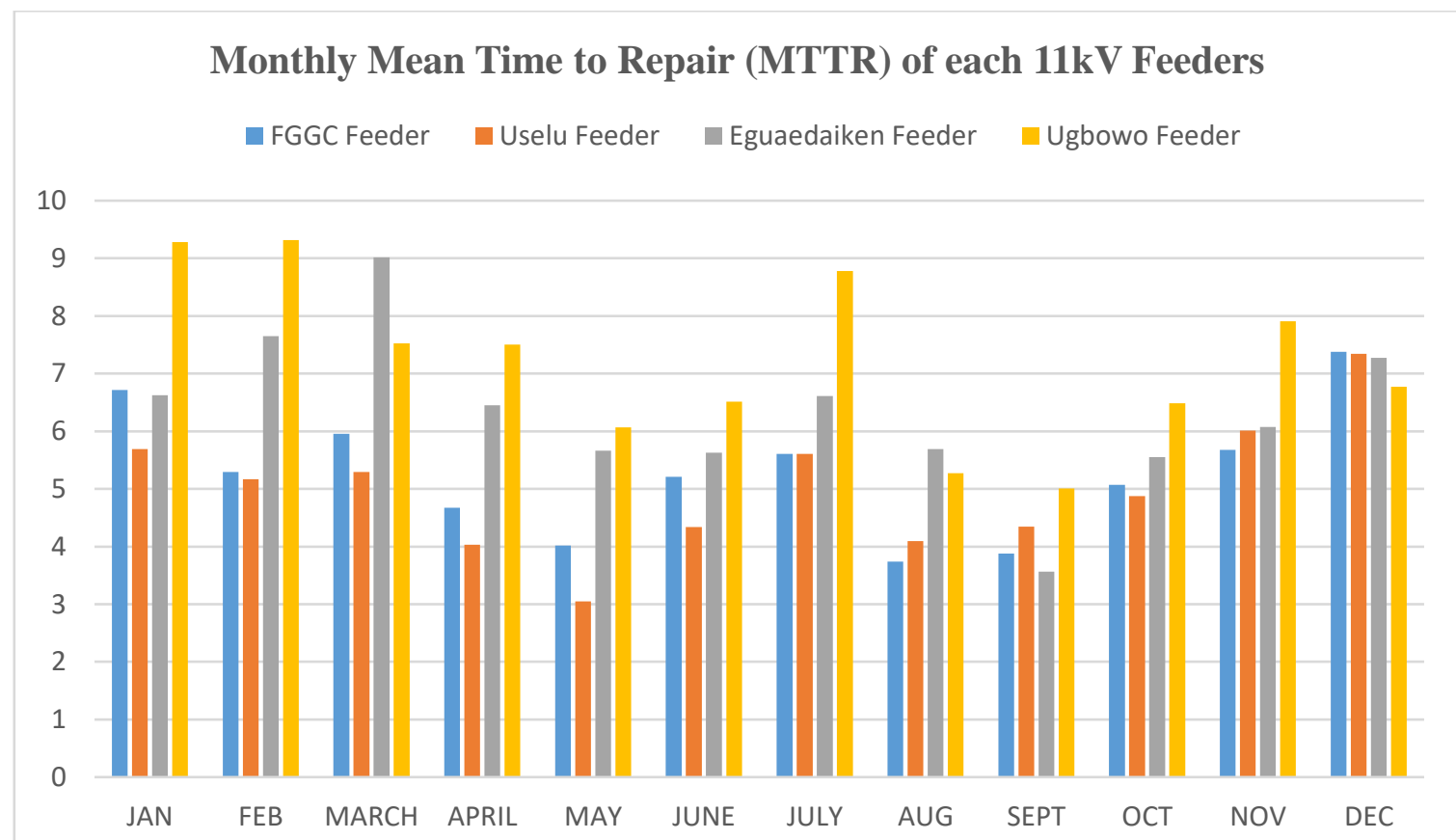

Figure 5: Monthly Mean Time to Repair of each $11 \mathrm{kV}$ Feeder of the Ugbowo 2x15MVA, 33/11kV Injection Substation 
F. O. Akpojedje and E.A. Ogujor / NIPES Journal of Science and Technology Research 2(3) 2020 pp. $314-327$

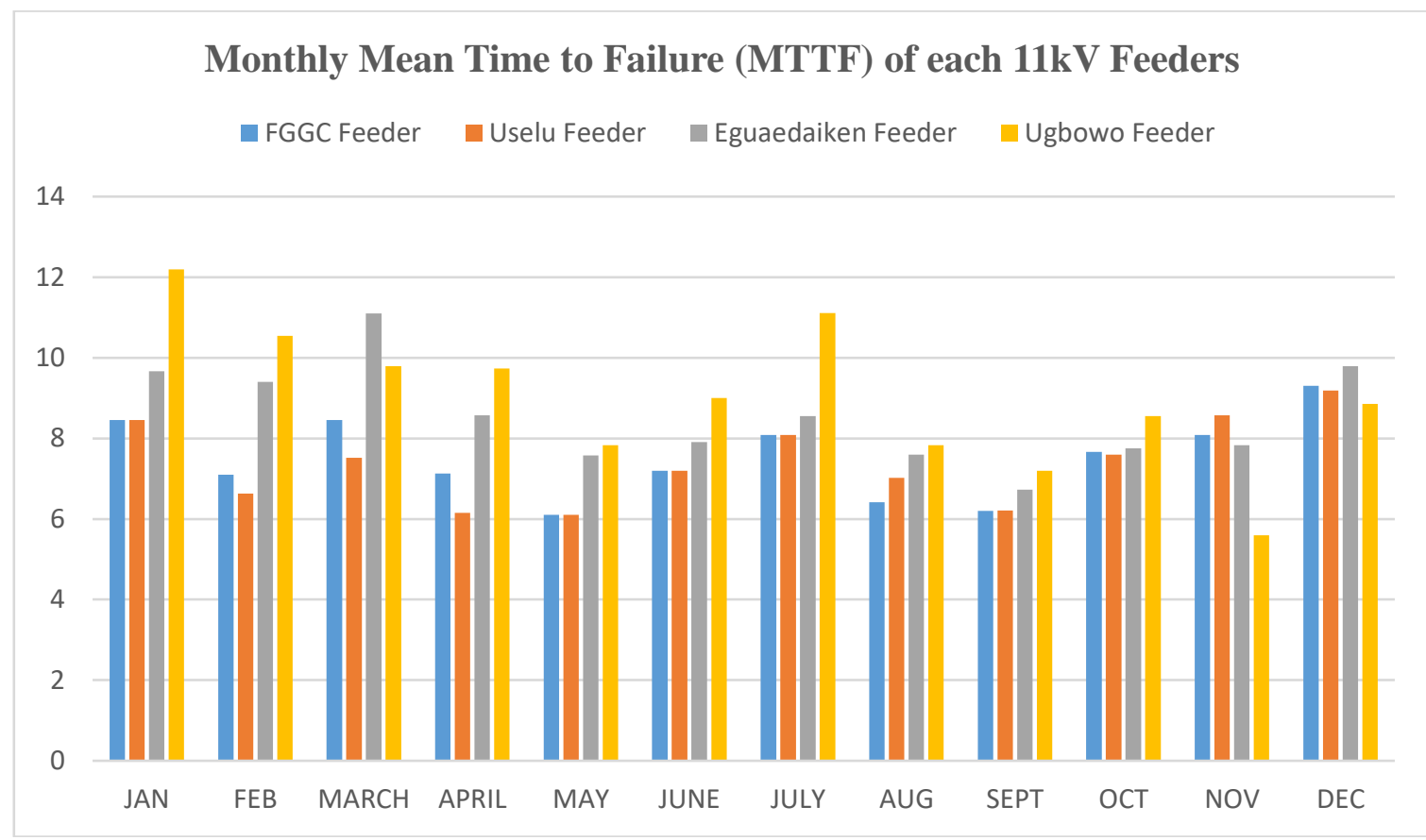

Figure 6: Monthly Mean Time to Failure of each 11kV Feeder of the Ugbowo 2x15MVA, 33/11kV Injection Substation

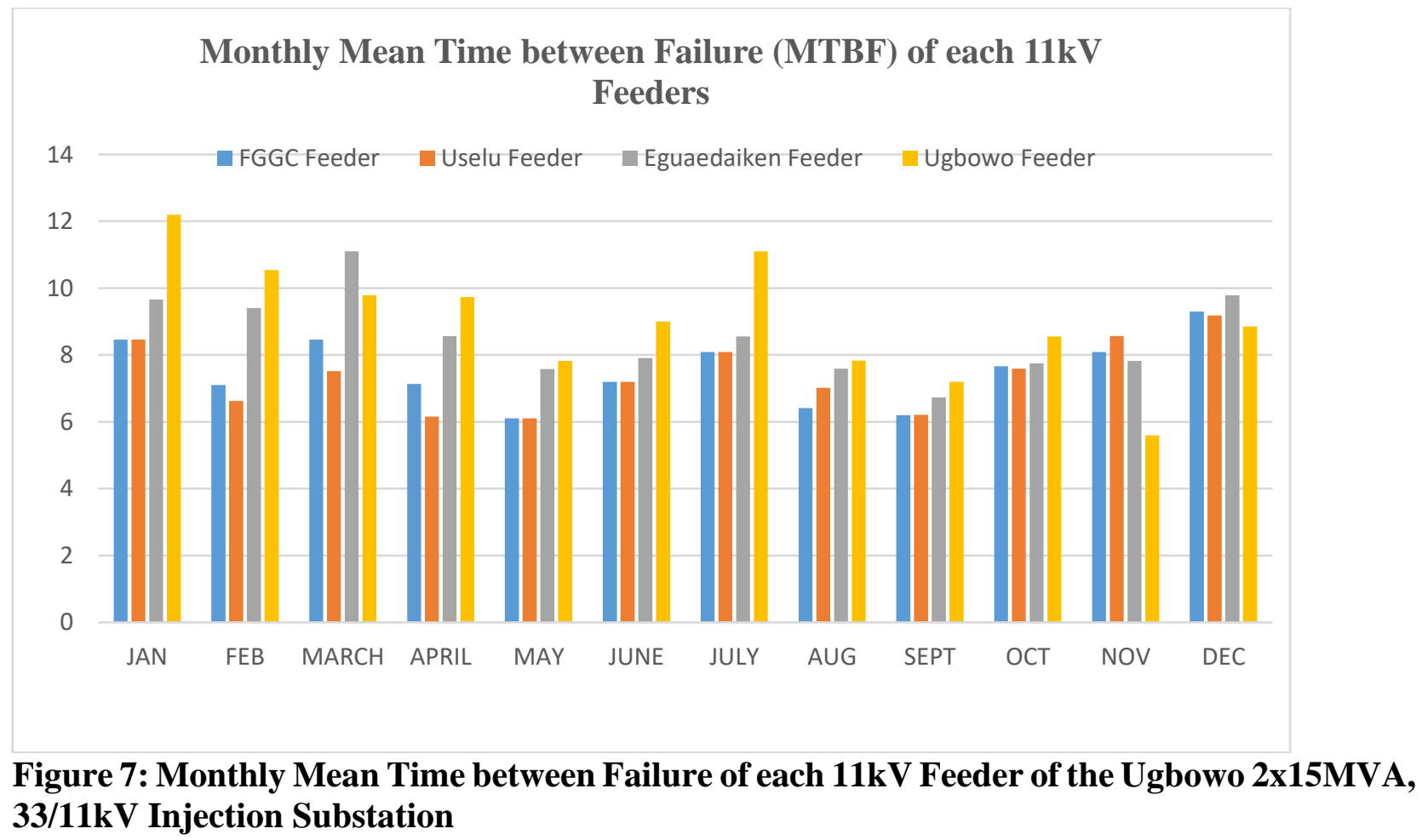


F. O. Akpojedje and E.A. Ogujor / NIPES Journal of Science and Technology Research 2(3) 2020 pp. $314-327$

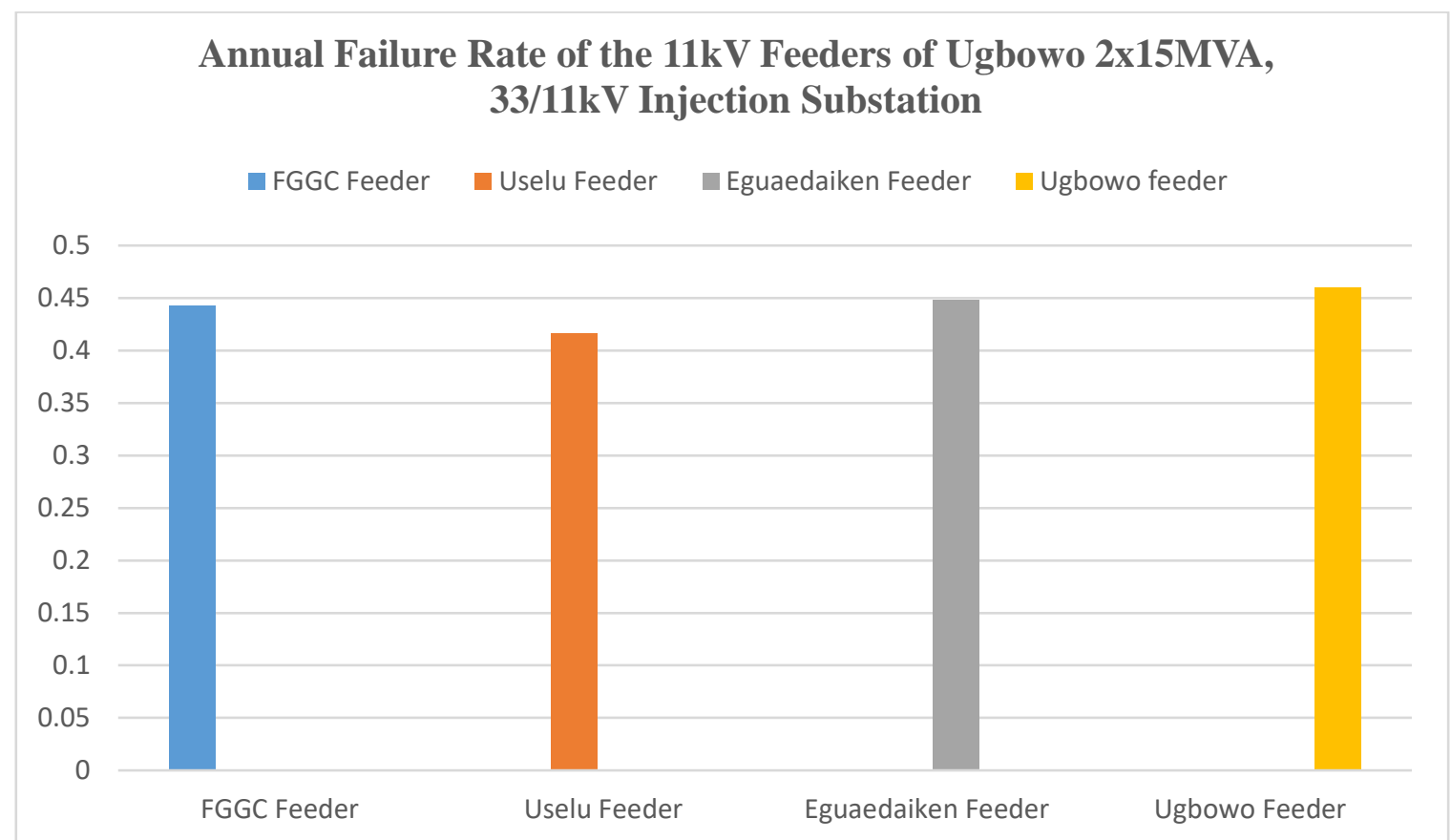

Figure 8: Annual Failure Rate of the Four Feeders of Ugbowo 2x15MVA, 33/11kV Injection Substation

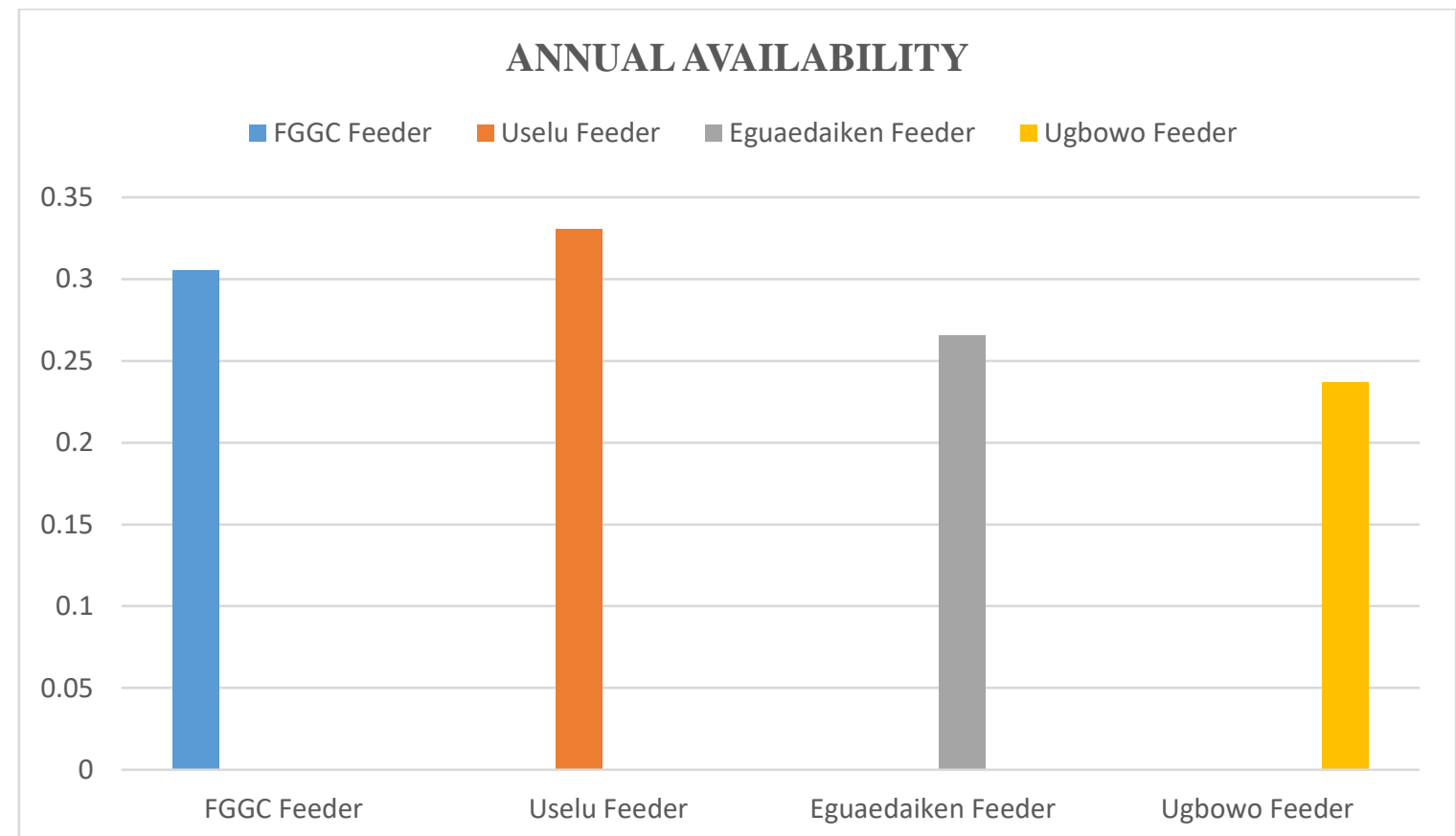

Figure 9: Annual Availability of each $11 \mathrm{kV}$ Feeder of the Ugbowo $2 \times 15 \mathrm{MVA}, 33 / 11 \mathrm{kV}$ Injection Substation 
F. O. Akpojedje and E.A. Ogujor / NIPES Journal of Science and Technology Research 2(3) 2020 pp. 314-327

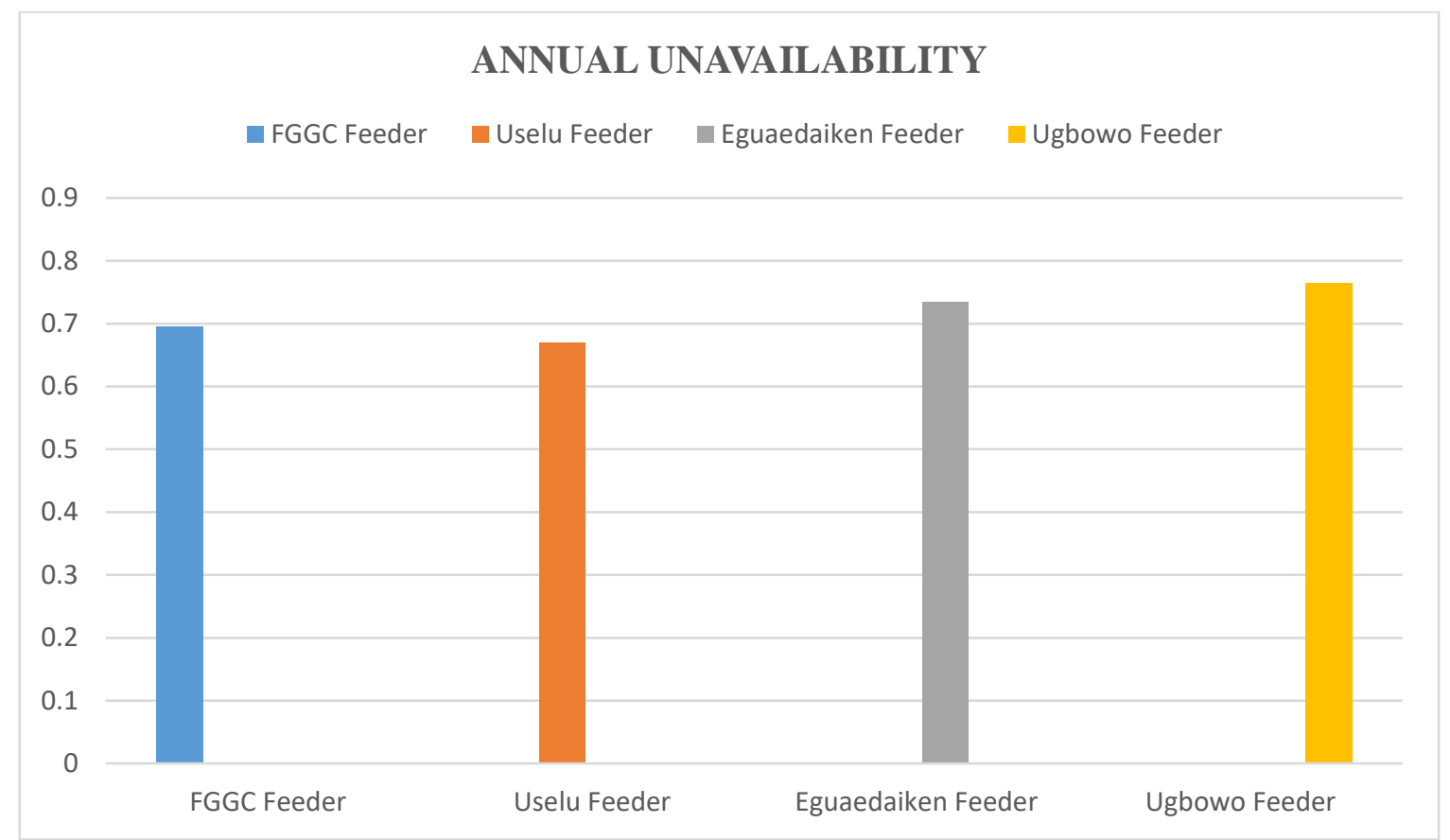

Figure 10: Annual Unavailability of each 11kV Feeder of the Ugbowo 2x15MVA, 33/11kV Injection Substation

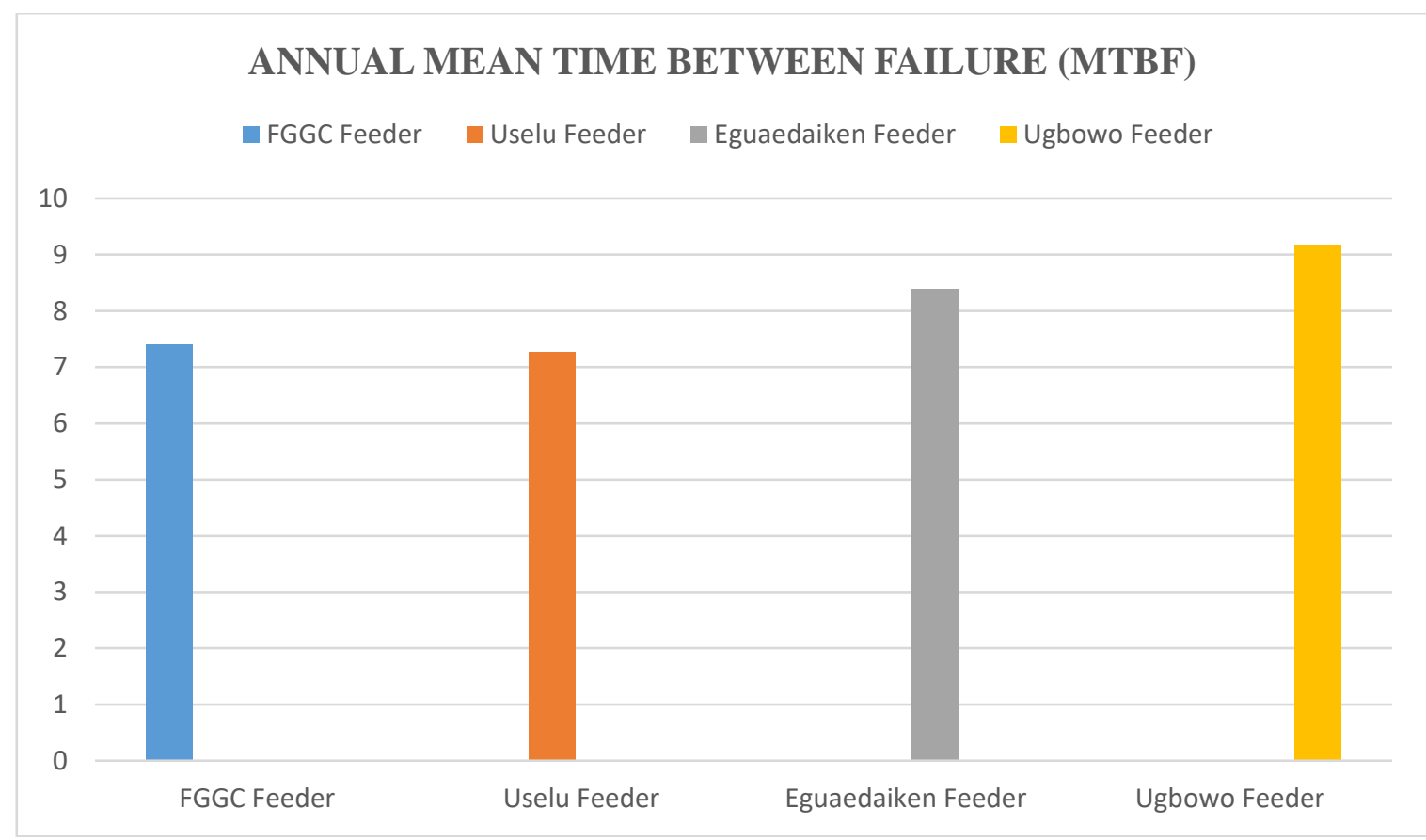

Figure 11: Annual Mean Time between Failure of each 11kV Feeder of the Ugbowo 2x15MVA, 33/11kV Injection Substation 
F. O. Akpojedje and E.A. Ogujor / NIPES Journal of Science and Technology Research 2(3) 2020 pp. 314-327

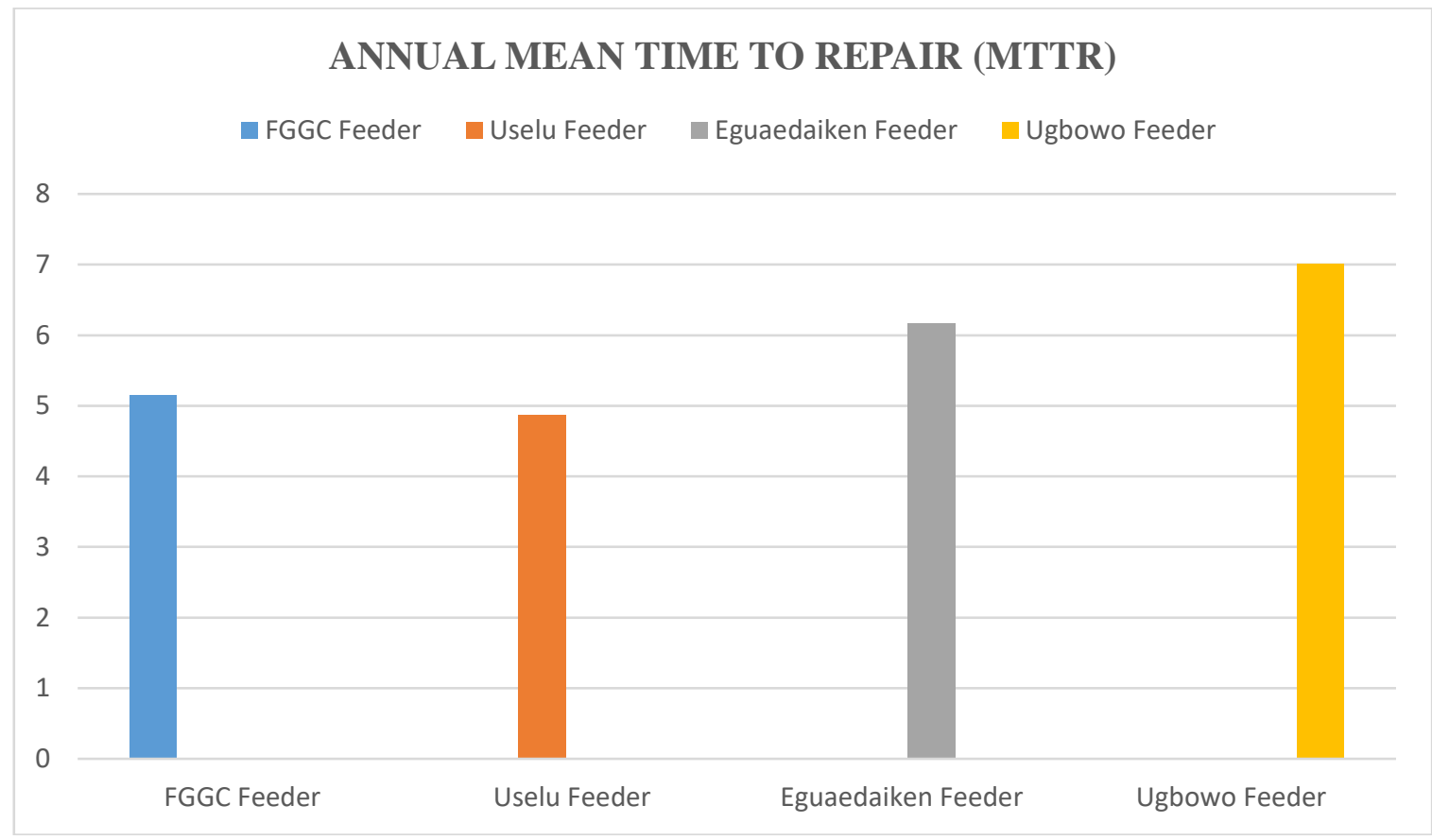

Figure 12: Annual Mean Time to Repair of each 11kV Feeder of the Ugbowo 2x15MVA, 33/11kV Injection Substation

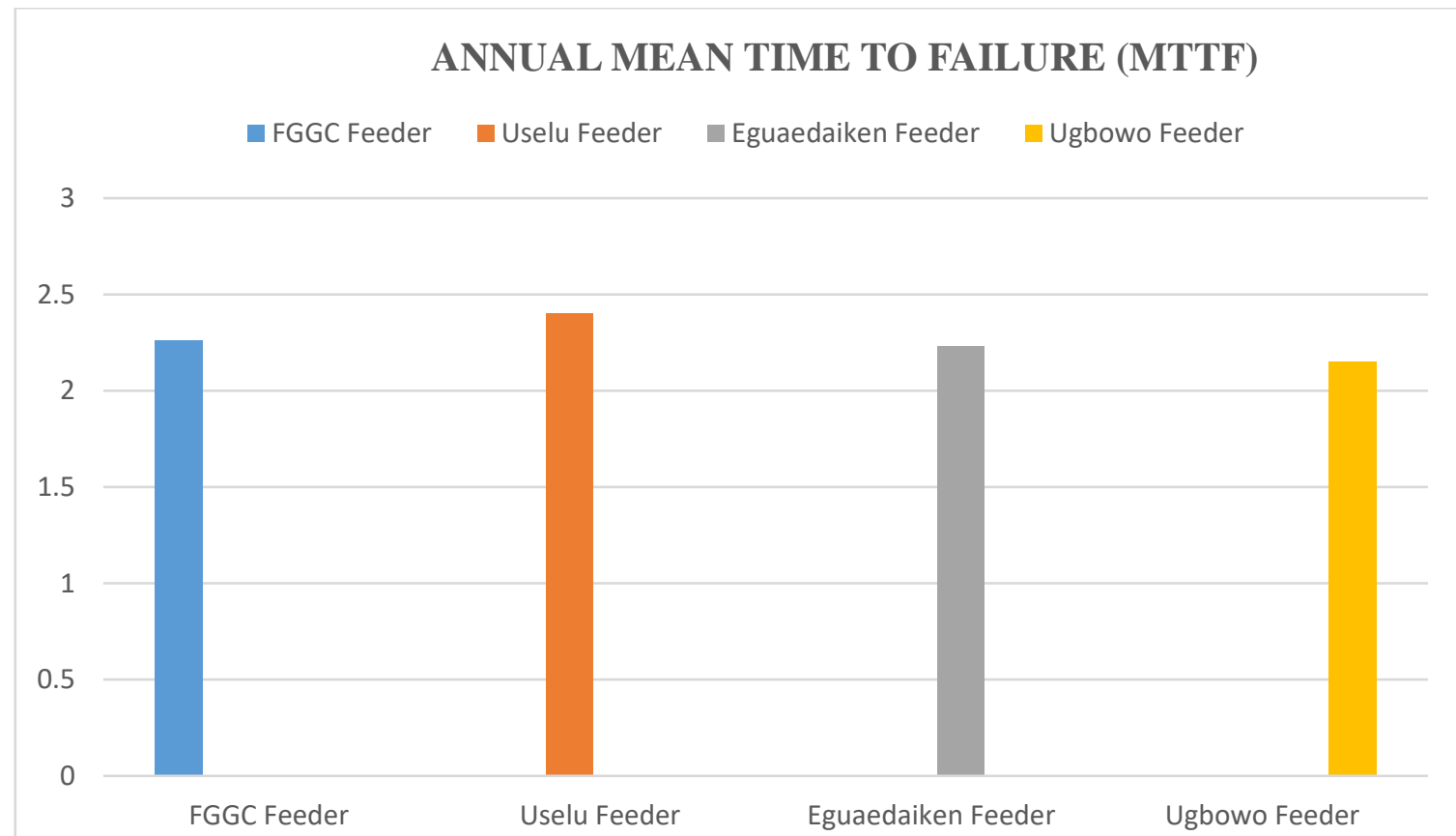

Figure 13: Annual Mean Time to Failure of each 11kV Feeder of the Ugbowo 2x15MVA, 33/11kV Injection Substation

\subsection{Discussion of Results}

The results of the frequent power outages of the Ugbowo $2 \times 15 \mathrm{MVA}, 33 / 11 \mathrm{kV}$ electric power distribution network has been determined and the outcomes interpreted graphically using Microsoft Excel is presented. Table 1 shows the monthly failure rate for each feeders of the network with Ugbowo $11 \mathrm{kV}$ feeder having the highest $81.5 \%$ in the month of February, followed by Uselu $11 \mathrm{kV}$ 
feeder $68.6 \%$ in the month February, FGGC $11 \mathrm{kV}$ feeder $57.5 \%$ in the month of January and Eguaedaiken $11 \mathrm{kV}$ feeder $56.7 \%$ in the month of February for the period under study; while Figure 1 and 2 shows the graphical interpretation of the feeders failure rates of the network. The monthly mean time to failure, mean time to repair and mean time between failure are presented in Table 2, 3 and 4 respectively. These reliability indices (RI) indicates the performance of the $11 \mathrm{kV}$ feeders for the period under study. It was observed that Eguaedaiken $11 \mathrm{kV}$ feeder have 3.04 in the month of January, 9.015 in the month of March and 11.103 in the month March as well respectively. The Uselu $11 \mathrm{kV}$ feeder have 3.049 in the month of May, 6.012 in the month of November and 11.103 in the month March respectively. Ugbowo $11 \mathrm{kV}$ feeder have 2.915 in the month of January, 9.279 in the month of January and 12.194 in the month of January respectively. While FGGC $11 \mathrm{kV}$ feeder have 2.674 in the month of August, 7.375 in the month of December and 9.301 in the month of December as well respectively with Figure 5, 6 and 7 showing the monthly graphical interpretation of the reliability indices (RI).

Table 5 and 6 depicts the availability and unavailability of the distribution network, while Figure 3 and 4 depicts the graphical interpretation of the unavailability and availability respectively for the electricity supply to consumers in the network. It was observed that Ugbowo $11 \mathrm{kV}$ feeder have the highest unavailability of electricity supply to consumers of $88.4 \%$ in the month of February, followed by Eguaedaiken $11 \mathrm{kV}$ feeder $81.2 \%$, Uselu $11 \mathrm{kV}$ feeder $80 \%$ and FGGC $11 \mathrm{kV}$ feeder $79.4 \%$ which is the least amongst the four feeders. This high level of unavailability of electricity supply to consumers is as a result of frequent power outages (cut) in the $11 \mathrm{kV}$ feeders of the Ugbowo $2 \times 15 \mathrm{MVA}, 33 / 11 \mathrm{kV}$ electric power distribution network. The high frequency of power outage is due to regimented load shedding (scheduled outages) currently practiced by the management of network and also, unscheduled (forced) outages as a result of faults occurrence. Additionally, Table 7 presents the annual computed reliability indices for the period under study, while Figure 8 to 13 shows the graphical interpretation of the annual failure rate, annual availability, annual unavailability, annual mean time between failure, annual mean time to repair and annual mean time to failure respectively for the distribution network.

Furthermore, Table 8 shows the System Performance Indices (SPI) of the injection substation which revealed that the annual total outage duration (SAIDI), outage frequency (SAIFI) and percentage availability (ASAI) were 175.7504 hours, 3.3780f/cu.yr and $97.99 \%$ which is a far cry from the international acceptable standard value (IASV) of 2.5 hours, 0.01 and $99.99 \%$ respectively and this has showed that the power supply services in the network is unreliable and unpredictable with customers at disadvantage. The frequent power outages are caused by the unscheduled and scheduled outages in the system which has a ripple effect on the reliability of the system vis-à-vis the economic growth and social well-being of the people of the locality. The poor power supply is further deepened as the demand for electric energy increase day by day. Since the demand for electric energy will be ever-increasing in the network; therefore, the onion is now on all stakeholders to buckle-up in order to savage the poor power supply in the locality to forestall further deepening of epilepsy of the electricity supply in the network. Frequent power cut and poor availability of electric power supply to consumers in the network calls for serious concern and intervention of both government and stakeholders.

\section{Conclusion and Recommendations}

In this paper, an attempt has been made to carry out the analysis of frequent power cut on the $11 \mathrm{kV}$ feeders of the Ugbowo 2x15MVA, 33/11kV electric power distribution network and its impact on the availability of electricity supply to consumers. The paper also stresses the cause of the frequent power outages in the distribution network and make appropriate recommendations that will remedy the current prevailing power situation in the distribution network. Introducing demand side management (DSM) and automated switching techniques with enhanced features is a way of 
modernizing the conventional electric grid. Therefore, power operators are encouraged to adopt novel methods to transform and manage the conventional techniques been used currently.

It is pertinent to say here that the Ugbowo $2 x 15 \mathrm{MVA}, 33 / 11 \mathrm{kV}$ electric power distribution network need urgent upgrading of equipment to forestall frequent outages in the $11 \mathrm{kV}$ feeders of the network. Hence, to achieve a better electric power availability in the network, the following are recommended: (i.). Automated feeder switching technique is needed to enhance quick restoration of electric power supply during fault. (ii). Optimal feeder configuration is required for quick isolation of faulty section and restoration of electricity supply to healthy section of the network. (iii). Upgrading of substation equipment to eliminate equipment limitation such as transformers limitation in the network in order to eliminate regimented load shedding in the network. (iv). The present energy management system should be rejig to improve it by adopting novel methods. (v). Customers' satisfaction should be the utility priority instead of profit driven orientation without achieving customer satisfaction.

\section{Acknowledgment}

The authors are grateful to the Benin Electricity Distribution Company (BEDC), Ugbowo branch for their assistance in getting relevant data used for this study. With high sincerity, the authors appreciate the contributions of the entire Distribution System Operators (DSOs) of Ugbowo injection substation for their immense contributions and assistance.

\section{References}

[1] F. O. Akpojedje, E. A. Ogujor and A. Folorunso (2018). Influence of Optimal Network Reconfiguration of Electric Power Distribution Feeders on Power Loss Minimization: A Comprehensive Review. IOSR-Journal of Electrical and Electronics Engineering (IOSR-JEEE), Vol. 13, Issue 2, Ver. I, pp. 42 - 56.

[2] B. U. Musa, T. M. Ngajia, B. M. Kalli and B. U. Tijjani (2015). Outage Analysis on Distribution Feeder in North East Nigeria. Journal of Multidisciplinary Engineering Science and Technology (JMEST), Vol. 2, Issue 1 , pp. $149-152$.

[3] J. E. Okhaifoh and J. Aghelegin, (2018). Reliability Assessment of the Etete and GRA 33kV Feeders in Benin Transmission Station, Benin City, Nigeria. Advances in Electrical and Telecommunication Engineering (AETE),Vol.1,Issue2,pp.85-92.Retrievedfrom: https://www.sciengtexopen.org/index.php/aete/article/view/333

[4] F. O. Akpojedje, E. A. Ogujor and M. O. Idode (2019). A Survey of Smart Grid Systems on Electric Power Distribution Network and Its Impact on Reliability. Journal of Advances in Science and Engineering (JASE), Vol. 2, Number 1, pp. 37 - 52. Retrieved from: https://www.scientexopen.org/index.php/jase/article/view/44

[5] A. E. Airoboman, E. A. Ogujor and I. K. Okakwu (2017). Reliability Analysis of Power System Network: A Case Study of Transmission Company of Nigeria, Benin City. IEEEPES-IAS Conference, Accra Ghana, June $27-30$, pp. $99-104$.

[6] F. O. Akpojedje, Y. O. Abu and C. B. Okoh, (2020). Statistical Analysis of Feeders' Reliability Metrics of the Ugbowo 2x15MVA, 33/11kV Electric Power Distribution System. Unpublished Manuscript.

[7] R. Billinton and N. R. Allan (1996). Reliability Evaluation of Power Systems (Second Ed.). Plenum Press, New York, pp. 220. 